\title{
PERTIMBANGAN HAKIM DALAM PUTUSAN PIDANA TERHADAP TINDAK PIDANA ASUSILA OLEH ANAK (Studi Kasus Pengadilan Negeri Kelas IA Padang)
}

\author{
Oleh: \\ Runi Viola \\ Email: runiviola@gmail.com \\ Fakultas Hukum Universitas Andalas
}

\begin{abstract}
ABSTRAK
Proses penjatuhan pemidanaan kasus Tindak Pidana Asusila yang Dilakukan Oleh Anak menjadi tugas yang berat bagi hakim karena harus mempunyai pandangan yang netral dalam membuat keputusan. Apalagi dengan melihat kasus kejahatan pidana yang dilakukan oleh anak bukan merupakan suatu kejahatan atau kenakalan anak biasa. Peran hakim yang besar dalam menangani perkara anak berkonsekuensi, hakim anak tersebut benar benar harus memahami kepentingan terbaik anak yang terutama (the best interest of the child). Adapun permasalahan yang diangkat yaitu : Apakah dasar pertimbangan hakim dalam menjatuhkan pidana Tindak Asusila yang dilakukan anak. Apakah kendala yang ditemui oleh hakim dalam pemidanaan kasus Tindak Asusila yang dilakukan anak. Bagaimanakah penyelesaian pemidanaan terhadap anak. Penulis menggunakan metode penelitian yuridis sosiologis yaitu pendekatan masalah melalui penelitian hukum dengan melihat norma hukum yang berlaku dan menghubungkannya dengan pelaksanaan dan fakta yang ada di lapangan.

Kata Kunci: Pertimbangan Hakim, Asusila, Tindak Pidana Anak
\end{abstract}

\begin{abstract}
The punishment for children committing misdemeanours brings the Justices into a complicated circumstance as they have to impartially examine these crimes. Moreover, misdemeanour committed by children is not merely juvenile delinquency. Thus, prior to establishing the verdict, judges should comprehensively define the best interest of the child. In this paper, the writer stated three objectives to examine: the judges' legal reasoning to condemn the children for the misdemeanours is, the obstacles which disrupt the judges to examine this crime, and the penal sentences for children committing the outward manners. This paper uses socio-legal method in which enables the writer to analyse the existing norms as well as define the relation between the norms and the facts.

Keywords: judge's legal reasoning, misdemeanour, crimes committed by children
\end{abstract}




\section{PENDAHULUAN}

Anak merupakan salah satu aset pembangunan nasional, patut dipertimbangkan dan diperhitungkan dari segi kualitas dan masa depannya. Tanpa kualitas yang handal dan masa depan yang jelas bagi anak, pembangunan nasional dan nasib bangsa akan sulit dibayangkan. Anak sebagai ahli waris dan pemegang nasib bangsa, ikut menentukan lajunya proses pembangunan nasional di segala bidang. Dalam pembangunan hukum, anak harus dikondisikan secara awal untuk memahami hak dan kewajiban masing-masing baik dalam kehidupan bermasyarakat, berbangsa dan bernegara. Pengkondisian ini diperlukan agar anak tidak menjadi korban atau objek dalam pembangunan ${ }^{1}$.

Harapan tersebut dikandaskan dengan kenakalan remaja dan tindak kejahatan yang dilakukan anak-anak secara kuantitatif dan kualitatif, semakin meningkat. Berdasarkan fenomena yang terjadi ternyata memperlihatkan perilaku anak banyak menjurus kepada tindak pidana kejahatan, seperti pemerkosaan, pencabulan, pencurian, perkelahian antar pelajar dan lain-lain, sehingga anak anak berhadapan dengan proses hukum yang disamakan dengan orang dewasa. Selain itu, anak yang kurang atau tidak memperoleh kasih sayang, bimbingan dan pembinaan dalam pengembangan sikap, perilaku, penyesuaian diri, serta pengawasan dari orang tua mudah terseret dalam arus pergaulan masyarakat dan lingkungan yang kurang sehat dan merugikan perkembangan pribadinya.

Hubungan orang tua dengan anak merupakan suatu hubungan yang hakiki, baik hubungan psikologis maupun mental sepiritualnya, mengingat ciri dan sifat anak yang khas, maka dalam menjatuhkan pidana atau tindakan terhadap Anak Nakal diusahakan agar anak tidak dipisahkan dari orang tuanya. Pengaruh kemajuan budaya, ilmu pengetahuan dan tekhnologi serta perkembangan pembangunan pada umumnya bukan saja terhadap orang dewasa, tetapi anakanak juga terjebak melanggar norma hukum. Masalah kenakalan anak menimbulkan kegelisahan di masyarakat. Kecendrungan meningkatkan kualitas maupun kuantitas pelanggaran, baik terhadap ketertiban umum maupun terhadap ketentuan perundang- undangan. Terhadap pelaku anak atau dengan kata lain meningkatnya kenakalan anak yang mengarah kepada tindakan kriminal,

\footnotetext{
${ }^{1}$ Bunadi Hidayat, Pemidanaan Anak Dibawah Umur, Alumni, Bandung : 2010.
} 
mendorong kita untuk lebih banyak memberikan perhatian akan penanggulangan dan penanganannya. Kasus yang paling memprihatinkan yaitu maraknya tindak pidana perkosaan yang dilakukan oleh anak di bawah umur.

Perilaku anak di bawah umur yang berkaitan dengan Tindak Pidana Asusila tidak cukup hanya dipandang sebagai kenakalan remaja biasa. Anak yang melakukan Tindak Pidana Asusila ini terjadi karena beberapa faktor diantaranya adalah rasa ingin tahu yang besar yang dimiliki oleh anak, banyaknya peredaran video porno, perkembangan teknologi hingga faktor sosial anak. Dalam Pasal 81 Undang-undang Nomor 23 Tahun 2002 tentang Perlindungan Anak mengatur tentang perbuatan asusila terhadap anak yang berbunyi sebagai berikut:

1. Setiap orang yang dengan sengaja melakukan kekerasan atau ancaman kekerasan memaksa anak melakukan persetubuhan dengannya atau orang lain, dipidana dengan pidana penjara paling lama 15 (lima belas) tahun dan paling singkat 3 (tiga) tahun dan denda paling banyak Rp. 300.000.000 (tiga ratus juta rupiah) dan paling sedikit Rp. 60.000.000 (enam puluh juta rupiah).

2. Ketentuan pidana sebagaimana dimaksud dalam ayat (1) berlaku pula bagi setiap orang yang dengan sengaja melakukan tipu muslihat, serangkaian kebohongan, atau membujuk anak melakukan persetubuhan dengannya atau orang lain.

Beberapa kasus yang sempat terjadi dan sangat memprihatinkan yakni kasus 6 orang anak dibawah umur melakukan pesta seks di Palembang ${ }^{2}$. Di Semarang, seorang anak yang berumur 15 tahun melakukan tindak pidana pemerkosaan kepada 2 orang anak perempuan berumur 10 tahun bersama 5 orang temannya. Pelaku melakukan tindakannya setelah menonton VCD porno sendiri ${ }^{3}$. Lain lagi yang terjadi di Muara Siberut, seorang murid SMA diketahui telah melakukan percobaan pemerkosaan terhadap rekan sekolahnya sendiri ${ }^{4}$. Dalam kasus tersebut, anak nakal didakwa dengan Pasal 287 ayat (1) KUHP Jo UU No. 3 Tahun 1997 Tentang Pengadilan Anak. Di kota Padang, terjadi kasus

\footnotetext{
${ }^{2}$ Detiknews.com, diakses tanggal 21 April 2012.

${ }^{3}$ Kompasiana.com tanggal 9 Mei 2011, diakses tanggal 21 April 2012.

${ }^{4}$ Pualligoubat.com tanggal 10 Februari 2012, dialses tanggal 22 April 2012.
} 
pemerkosaan yang dilakukan oleh 3 pelajar salah satu SMA swasta ${ }^{5}$. Mereka melakukan pemerkosaan secara bergilir kepada salah satu rekan sekolah nya diatas sebuah mobil.

Pertanggung jawaban pidana anak dibawah umur ini, menjadi hal yang masih diperdebatkan oleh beberapa ahli, Moeljatno menyatakan bahwa dalam pembicaraan tentang perbuatan atau tindak pidana tidak termasuk pertanggungjawaban pidana. Perbuatan pidana hanya menunjuk pada dilarang atau diancamnya perbuatan dengan pidana. Moeljatno menyatakan bahwa orang dapat dikatakan mempunyai kesalahan, jika ia pada waktu melakukan perbuatan pidana dilihat dari segi masarakat dapat dicela karenanya, yaitu kenapa melakukan perbuatan yang merugikan masyarakat padahal ia mampu untuk mengetahui makna (jelek) perbuatan tersebut. Kemampuan untuk mengetahui makna tersebutlah yang mendasari pemikiran Moeljatno kemudian bahwa terhadap anak kecil termasuk orang gila tidak dapat diipersalahkan karena melakukan perbuatan yang tidak dipahaminya bahwa perbuatan itu dilarang ${ }^{6}$.

Menghadapi perbuatan anak dibawah usia 16 tahun, hakim harus menyelidiki dengan sangat teliti. Pemberlakuan beberapa peraturan dalam melaksanakan putusan pidana yang dilakukan anak dibawah umur menjadi pertimbangan hakim dalam memutuskannya. Di dalam KUHP sebagai Undangundang Hukum Pidana dari produk hukum kolonial Belanda yang sampai saat ini masih dipakai di Indonesia, hanya mengatur beberapa pasal mengenai tindak pidana anak. Undang-undang No 3 Tahun 1997 Tentang Pengadilan Anak yang sudah berlaku saat ini secara khusus mekanisme pemidanaan dan pemberian tindakan terhadap anak pelaku tindak pidana yang masih berusia kurang dari 18 tahun. Dalam Undang-Undang Tentang Pengadilan Anak terdapat pengaturan tentang batas usia anak yang menjadi kompetensi absolutnya, sanksi pidana yang dapat diancamkan, hukum acara, dan tindakan (maatregel) bagi anak nakal pelaku tindak pidana (anak nakal dan anak yang melakukan perbuatan yang terlarang bagi anak). Proses penjatuhan pidana kepada anak nakal, juga memperhatikan halhal yang terkandung dalam Undang- undang Nomor 23 Tahun 2002 Tentang Perlindungan Anak yang disebutkan didalam nya segala kegiatan untuk

\footnotetext{
${ }^{5}$ KlikSumbar.com tanggal 4 Mei 2012, diakses tanggal 26 Agustus 2012.

${ }^{6}$ Moeljatno. Asas-asas Hukum Pidana, Edisi Revisi. Rineka Cipta. Jakarta: 2008, hlm 165.
} 
menjamin dan melindungi anak dan hak-haknya agar dapat hidup, tumbuh, berkembang dan berpartisipasi, secara optimal sesuai dengan harkat dan martabat kemanusiaan, serta mendapat perlindungan dari kekerasan dan diskriminasi. Sedangkan dalam Pasal 1 butir ke 15 dalam Undang-undang Perlindungan Anak juga menyebutkan tentang perlindungan khusus bagi anak adalah perlindungan yang diberikan kepada anak dalam situasi darurat, anak berhadapan dengan hukum.

Selain itu pembedaan tersebut dimaksudkan untuk memberi kesempatan kepada anak melalui pembinaan akan diperoleh jati dirinya untuk menjadi manusia yang mandiri, bertanggung jawab,dan berguna bagi diri, keluarga, masyarakat, bangsa dan negara ${ }^{7}$. Tugas hakim dalam menjatuhkan pidana terhadap anak, menjadi sangat berat dan penuh pertimbangan. Butuh ketelitian dan pandangan yang netral dalam menghadapi kasus seperti ini. Hakim dalam membuat putusan harus memperhatikan segala aspek di dalamnya, mulai dari perlunya kehati-hatian, dihindari sekecil mungkin ketidakcermatan, baik yang bersifat formal maupun materiil sampai dengan adanya kecakapan teknik membuatnya. Oleh karena itu hakim tidak berarti dapat berbuat sesuka hatinya, melainkan hakim juga harus mempertanggung jawabkan putusannya ${ }^{8}$.

Demikian tanpa mengecilkan arti dari lembaga penegak hukum yang lain, maka mau tidak mau titik sentral penanganan anak nakal bertitik tumpu di tangan hakim anak, hakim anaklah sesuai Undang-Undang No.3 Tahun 1997 yang mempunyai peran besar mengemban amanat penanganan anak nakal berdasarkan kepentingan terbaik anak (the best interest of the child). Undang-Undang memberikan peran aktif dan dominan kepada hakim (anak) dalam proses pemidanaan, dibandingkan dengan peran penyidik dan penuntut umum. Peran hakim yang besar dalam menangani perkara anak berkonsekuensi, hakim anak tersebut benar-banar harus memahami kepentingan terbaik anaklah yang terutama (the best interest of the child). Putusan yang diambil haruslah dapat memberikan keadilan sehingga berguna dan bermanfaat bagi anak.

\footnotetext{
${ }^{7}$ Bunadi Hidayat., Op Cit, Hlm 16.

${ }^{8}$ Ahmad Rifai. Penemuan Hukum oleh Hakim Dalam Persfektif Hukum Progresif. Sinar Grafika. Jakarta: 2010 hlm 94.
} 
Melihat dari banyaknya kasus asusila yang dilakukan oleh anak terjadi, fenomena ini tentu menimbulkan beberapa pertanyaan, sehingga Penulis tertarik untuk mengangkat penelitian yang berjudul PERTIMBANGAN HAKIM DALAM PUTUSAN PIDANA TERHADAP TINDAK PIDANA ASUSILA OLEH ANAK (Studi Kasus Pengadilan Negeri Kelas IA Padang).

\section{RUMUSAN MASALAH}

Berdasarkan uraian latar belakang yang telah dikemukakan diatas, maka ada beberapa permasalahan, yaitu:

1. Apakah dasar pertimbangan hakim dalam menjatuhkan pidana Tindak Asusila yang dilakukan anak di Pengadilan Negeri Kelas IA Padang ?

2. Apakah kendala yang ditemui oleh hakim dalam pemidanaan kasus Tindak Asusila yang dilakukan anak di Pengadilan Negeri Kelas IA Padang?

3. Apakah bentuk putusan yang dijatuhkan oleh hakim terhadap Tindak Pidana Asusila yang dilakukan anak di Pengadilan Negeri Kelas IA Padang ?

\section{METODE PENELITIAN}

Tipe metode yang digunakan dalam penelitian ini adalah yuridis sosiologis (sociological Research) yang menekankan pada praktik di lapangan dikaitkan dengan aspek hukum atau perundang-undangan yang berlaku berkenaan dengan objek penelitian yang dibahas dan melihat norma-norma hukum yang berlaku kemudian dihubungkan dengan kenyataan atau fakta-fakta yang terdapat dalam kehidupan masyarakat. ${ }^{9}$

\section{PEMBAHASAN}

${ }^{9}$ Amirudin dan Zainal Asikin, Pengantar Metode Penelitian Hukum. PT. Raja Grafindo Persada. Jakarta: 2008. 
A. Pertimbangan Hakim Dalam Menjatuhkan Putusan Tindak Pidana Asusila Yang Dilakukan Oleh Anak di Pengadilan Negeri Kelas 1A Padang Adapun yang menjadi dasar pertimbangan hakim dalam memutus perkara pidana Nomor 454/Pid.B/2012/PN.Bpp. di Pengadilan Negeri Kelas IA Padang tersebut yakni :

1. Keterangan-keterangan yang terjadi selama persidangan, baik keterangan yang diberikan oleh anak nakal, maupun keterangan yang diberikan oleh korban dan para saksi.

2. Bahwa dipersidangan telah dibacakan Visum et Repertum yang menyatakan bahwa korban yang berusia 15 (lima belas) tahun telah didapat kan tanda- tanda pasti seorang wanita hamil dengan usia kehamilan lebih kurang dua puluh empat minggu dan tanda- tanda janin dalam rahim dengan usia janin kurang lebih dua puluh mepat minggu.

3. Bahwa anak didakwa dengan dakwaan alternatif yakni kesatu, melanggar Pasal 81 ayat (2) UU No. 23 Tahun 2002 Tentang Perlindungan Anak jo UU No. 3 Tahun 1997 Tentang Pengadilan Anak atau kedua, melanggar Pasal 287 ayat (1) jo UU No. 3 Tahun 1997 Tentang Pengadilan Anak.

4. Bahwa unsur-unsur tindak pidana yang didakwakan Penuntut Umum dalam dakwaan primer melanggar Pasal 81 ayat (2) UU No. 23 Tahun 2002 Tentang Perlindungan Anak tentang yang harus dipertimbangkan adalah sebagai berikut :

\section{Setiap Orang}

2. Dengan sengaja melakukan tipu muslihat, serangkaian kebohongan atau membujuk anak melakukan persetubuhan dengannya.

5. Bahwa menurut putusan Mahkamah Agung R.I Nomor 1398/K/Pid/1994 Tanggal 30 Juni 1995 kata "setiap orang" adalah sama dengan terminologi kata "barang siapa". Jadi yang dimaksud dengan "setiap orang" disini adalah setiap orang atau pribadi yang merupakan subjek hukum dari pada suatu perbuatan pidana yang dpat dimintai pertanggung jawaban.

6. Bahwa Penuntut Umum telah mendakwa anak melakukan suatu perbuatan pidana sebagaimana tercantum dalam surat dakwaan tertanggal 24 Agustus 2012. 
7. Bahwa anak membenarkan identitas yang tercantum dalam surat dakwaan tersebut, dengan demikian yang dimaksud dengan barang siapa disini adalah anak nakal yang namanya dirahasiakan, oleh karena itu unsur setiap orang telah terpenuhi.

8. Bahwa unsur "dengan sengaja" dalam perkara in casu harus dilihat dari tujuan atau niat yang harus dimiliki oleh terdakwa.

9. Bahwa yang dimaksud dengan melakukan "tipu muslihat" adalah siasat dengan maksud untuk menakalai agar anak yang namanya dirahasiakan dapat memperdaya "korban/anak" untuk mencapai kehendaknya in casu dalam hal ini melakukan persetubuhan dengannya.

10. Bahwa menurut ketentuan Pasal 1 angka 1 UU No. 23 tahun 2002 Tentang Perlindungan Anak, yang dimaksud dengan anak adalah seseorang yang belum berusia 18 (delapan belas) tahun, termasuk anak yang berada di dalam kandungan.

11. Bahwa dari pengertian-pengertian tersebut dapatlah disimpulkan bahwa untuk terpenuhinya unsur ini harus ada kehendak atau maksud dari anak nakal yang namanya dirahasiakan untuk melakukan tipu muslihat, membujuk anak melakukan persetubuhan dengannya.

12. Bahwa dari keterangan saksi-saksi dan keterangan anak nakal yang namanya dirahasiakan dihubungkan denagn Visum et Repertum dan kutipan akta kelahiran atas anak saksi korban yang namanya dirahasiakan yang bersesuaian satu sama lain terungkap dipersidangan.

13. Bahwa sebelum melakukan tindakan asusila tersebut, anak nakal memberikan saksi korban berupa tablet berwarna kuning yang bertujuan agar saksi korban fly, oleh karena itu hakim berkeyakinan bahwa anak nakal yang namanya dirahasiakan telah membujuk saksi korban untuk menyetubuhinya.

14. Bahwa dari keterangan saksi-saksi dihubungkan dengan Kutipan Ijazah Sekolah Dasar Tertanggal 22 Juni 2009 dan Visum et Repertum Nomor: VER/178/VII/2012/RUMKIT pada tanggal 19 Juli 2012, ternyata bahwa saksi korban lahir tanggal 15 November 1997, oleh karenanya terbukti secara sah dan meyakinkan bahwa ia anak bernama dirahasiakan 
melakukan perbuatan persetubuhan terhadap saksi korban ketika saksi korban berumur 14 (empat belas) tahun sedangkan ia, anak nakal yang namanya dirahasiakan sebagaimana kutipan akta kelahiran Nomor: 2112/1920/04/T yang lahir pada tanggal 28 Oktober 1994 baru berumur 17 (tujuh belas) tahun. Oleh karena itu perbuatan anak yang namanya dirahasiakan telah memenuhi unsur "dengan sengaja melakukan tipu muslihat atau membujuk anak melakukan persetubuhan dengannya”.

15. Bahwa atas dasar pertimbangan hukum tersebut diatas, perbuatan anak nakal yang namanya dirahasiakan telah memenuhi unusr-unsur tindak pidana sebagaimana yang didakwakan Penuntut Umum melanggar Pasal 81 ayat (2) UU No. 23 Tahun 2002 Tentang Perlindungan Anak.

16. Bahwa oleh karena perbuatan anak nakal yang namanya dirahasiakan telah memenuhi unsur-unsur tindak pidana yang didakwakan Penuntut Umum, maka perbuatan anak nakal tersebut telah terbukti secara sah dan meyakinkan bersalah melakukan perbuatan pidana " dengan sengaja membujuk anak dibawah umur melakukan persetubuhan dengannya".

17. Bahwa oleh karena anak yang namanya dirahasiakan telah terbukti bersalah melakukan perbuatan pidana sedangkan dari Laporan Hasil Penelitian Kemasyarakatan untuk Penyidikan/Sidang Pengadilan Anak terhadap anak nakal usianya baru 17 (tujuh belas) tahun, maka harus dipersalahkan dan dinyatakan sebagai Anak Nakal.

18. Bahwa menurut Pasal 23 ayat (1) jo Pasal 26 ayat (3) UU No.3 Tahun 1997 Tentang Pengadilan Anak bahwa dapat dijatuhkan pidana kepada Anak Nakal yang usianya diatas 12 (dua belas) tahun.

19. Bahwa karena anak nakal dipersalahkan melakukan perbuatan pidana, maka harus dijatuhi hukuman.

20. Bahwa majelis hakim tidak melihat alasan-alasan yang dapat menghapus pertanggung jawaban anak nakal, dan tidak pula terdapat alasan pembenar sehingga oleh karenanya anak nakal harus dijatuhi hukuman. Dan sebelum menjatuhkan hukuman akan dipertimbangkan fakta-fakta yang dapat dipandang sebagai hal-hal yang memberatkan atau meringankan :

a. Hal-hal yang meringankan : 
1) Perbuatan anak nakal dilakukan lebih dari satu kali;

2) Anak nakal tidak mau bertanggung jawab atas janin yang dikandung oleh saksi korban, dan disamping itu perbuatan anak nakal dapat merusak masa depan korban

b. Hal-hal yang meringankan yakni, anak nakal sama sekali belum pernah dihukum pidana.

\section{B. Kendala Yang Ditemui Hakim Dalam Pemidanaan Kasus Tindak Pidana Asusila Yang Dilakukan Anak di Pengadilan Negeri Kelas 1A Padang}

Dalam memutuskan perkara pidana asusila oleh anak, hakim terkadang menghadapi beberapa kendala. Menurut salah satu hakim Pengadilan Negeri Kelas 1A Padang, Bapak Kamijon., SH kendala yang ditemui hakim dalam pemidanaan kasus asusila oleh anak antara lain ${ }^{10}$ :

1. Dalam pemeriksaan persidangan, anak biasanya mengelak dari keterangan saksi dan tidak mengakui perbuatannya.

2. Keyakinan hakim terhadap alasan yang dikemukakan oleh anak nakal dalam melakukan Tindak Pidana Asusila.

3. Laporan petugas Badan Pemasyarakatan (BAPAS)

4. Adanya penolakan dari elemen organisasi perlindungan anak

\section{Bentuk Putusan Hakim Terhadap Anak Dalam Kasus Asusila di Pengadilan Negeri Kelas 1A Padang}

Dalam kasus asusila di Pengadilan Negeri Kelas 1A Padang dengan Nomor Perkara 454/Pid.B/2012/PN.Bpp. yang diputus pada tanggal 17 September 2012 oleh Hakim Tunggal, Jaksa Penuntut Umum mendakwa anak nakal dengan Pasal 81 ayat 2 UU Nomor 23 Tahun 2002 Tentang Perlindungan Anak Jo UU Nomor 3 Tahun 1997 Tentang Pengadilan Anak. Serta menjatuhkan pidana terhadap terdakwa dengan pidana penjara selama 6 (enam) tahun dikurangi selama terdakwa berada dalam tahanan dan denda sebesar Rp. 60.0000.000 (enam puluh juta rupiah).

Dalam putusan hakim tunggal menyatakan sebagai berikut :

\footnotetext{
${ }^{10}$ Hasil wawancara dengan Bapak Kamijon., SH di Pengadilan Negeri Kelas 1A Padang pada hari Selasa tanggal 5 Maret 2013 pukul 10.00 WIB.
} 
1. Menyatakan anak terbukti secara sah dan meyakinkan bersalah melakukan perbuatan pidana "dengan sengaja membujuk anak melakukan persetubuhan dengannya";

2. Menyatakan anak sebagai anak nakal;

3. Menghukum anak nakal dengan pidana penjara selama 4 tahun, dan hukuman denda sebesar Rp. 60.000.000,- (enam puluh juta rupiah ) dengan ketentuan apabila hukuman denda tidak dibayar diganti dengan hukuman kurungan selama 1 (satu) bulan;

4. Menyatakan masa penahanan yang telah dijalani anak nakal dikurangkan seluruhnya dari lamanya pidana yang dijatuhkan;

5. Menyatakan anak nakal ditahan dalam Rumah Tahanan Negara;

6. Membebankan biaya perkara kepada anak nakal sebesar Rp. 1000,- (seribu rupiah).

Dalam penjatuhan pidana ini, hakim menggunakan Pasal 81 ayat 2 UU No. 23 Tahun 2002 Tentang Perlindungan anak. Dimana, korban yang merupakan anak dibawah umur yang dibujuk oleh pelaku untuk melakukan persetubuhan diancam pidana penjara paling lama 15 (lima belas) tahun dan paling singkat 3 (tiga) tahun. Hakim menjatuhkan hukuman penjara selama 4 tahun sesuai dengan Pasal 26 ayat 1 UU No. 3 Tahun 1997 Tentang Pengadilan Anak yang menyebutkan bahwa pidana penjara dapat dijatuhkan kepada anak nakal paling lama $1 / 2$ (satu per dua) dari maksimum ancaman penjara bagi orang dewasa. 


\section{PENUTUP}

Berdasarkan hasil dan pembahasan yang telah dikemukakan sebelumnya maka dapat disimpulkan sebagai berikut :

1. Dalam kasus yang diteliti, akibat perbuatan pelaku korban menjadi hamil dan pelaku tidak mau bertanggung jawab. Yang kedua yakni hakim membuat putusan juga berdasarkan kepada laporan penelitian yang dibuat oleh petugas Badan Pemasyarakatan (BAPAS). Karena berdasarkan kepada penjelasan Pasal 25 UU No. 3 Tahun 1997 Tentang Pengadilan Anak yang menyebutkan bahwa Hakim harus memperhatikan kepada laporan penelitian yang dibuat oleh Pembimbing Kemasyarakatan sebagai pertimbangan dalam memutuskan perkara tindak pidana yang dilakukan oleh anak nakal.

2. Kendala yang dihadapi oleh hakim dalam memutuskan pemidanaan Tindak Pidana Asusila yang dilakukan oleh anak ini yakni, anak nakal seringkali tidak mengakui perbuatannya dan beralasan bahwa tindakan asusila tersebut ia lakukan dengan korban berdasarkan keinginan bersama atau suka sama suka. Ini jelas mempersulit hakim dalam memutuskan pidananya. Karena di pihak korban tidak menerima perbuatan anak nakal tersebut.

3. Bentuk putusan hakim terhadap anak nakal Tindak Pidana Asusila di Pengadilan Negeri Kelas IA Padang dalam perkara Nomor 454/Pid.B/2012/PN.Bpp. hakim memutuskan bahwa anak nakal telah terbukti melanggar Pasal 81 ayat 2 UU No. 23 Tahun 2002 Tentang Perlindungan Anak Jo UU No. 3 Tahun 1997 Tentang Pengadilan Anak dan menghukum anak nakal dengan pidana penjara selama 4 (empat) tahun dan hukuman denda sebesar Rp. 60.000.000,- (enam puluh juta rupiah) dengan ketentuan apabila hukuman denda tidak dibayar maka diganti dengan hukuman kurungan selam 1 (satu) bulan. 